\title{
MENINGKATKAN KEMAMPUAN KOMUNIKASI MATEMATIS SISWA SD MELALUI MODEL PEMBELAJARAN KOOPERATIF TIPE QUESTION STUDENTS HAVE DAN TIPE FISHBOWL
}

\author{
Debi Tanti Adam ${ }^{1}$; Sonya Fanny Tauran ${ }^{2}$ \\ Program Studi Pendidikan Matematika \\ FKIP Universitas Advent Indonesia \\ 1.debbyadam134@gmail.com, ${ }^{2}$ fanny_tauran@yahoo.com
}

\begin{abstract}
Abstrak: Komunikasi matematis merupakan kemampuan siswa untuk menerangkan ide-ide matematika baik secara lisan maupun tertulis. Namun kemampuan komunikasi matematis siswa saat ini masih sangat rendah jika dibandingkan dengan negaranegara lain. Tujuan penelitian ini adalah untuk mengetahui apakah terdapat perbedaan peningkatan kemampuan komunikasi matematis siswa yang memperoleh model pembelajaran kooperatif tipe Question Students Have atau tipe Fishbowl, dan mengetahui respon siswa terhadap model pembelajaran. Sampel dalam penelitian ini adalah siswa kelas VA dan VC, SD KARTIKA X-3 Parongpong, Bandung Barat. Instrumen yang digunakan adalah tes kemampuan komunikasi matematis berupa soal uraian terkait dengan materi "Pengumpulan dan Penyajian Data Tunggal". Uji statistik yang digunakan adalah uji beda dua ratarata, t-tes pada taraf signifikan 0,05 . Hasil penelitian menunjukkan bahwa (1) Peningkatan kemampuan komunikasi matematis siswa melalui model pembelajaran kooperatif tipe Question Students Have dan tipe Fishbowl berada pada kategori sedang. (2) Tidak terdapat perbedaan yang signifikan pada peningkatan kemampuan komunikasi matematis antara siswa yang memperoleh model pembelajaran kooperatif tipe Question Students Have dan siswa yang memperoleh model pembelajaran tipe Fishbowl. (3) Respon siswa terhadap pembelajaran matematika dengan mengunakan model pembelajaran kooperatif tipe Question Students Have berada pada kategori "suka" dan tipe Fishbowl berada pada kategori "sangat suka".
\end{abstract}

Kata Kunci: Komunikasi Matematis, Pembelajaran Kooperatif, Question Students Have, Fishbowl

Abstract: Mathematical communication is the ability of students to explain mathematical ideas both verbally and writing. But students' mathematical communication skills are still very low compared to other countries. The purpose of this research was to find out whether there were an increase in mathematical communication skills of students who obtained the cooperative learning model Question Students Have or Fishbowl type, and the students' responses to the learning model. The sample in this research were students of VA and VC, SD KARTIKA X-3 Parongpong, West Bandung. The instrument used is a mathematical communication skills test in the form of subjective questions related to the material "Collection and Presentation of Single Data". The statistical test used is a two-mean difference test, $t$-test at a significant level of 0.05 . The results showed that (1) The increase of students' mathematical communication skills through cooperative learning models Question Students Have and Fishbowl types were in the medium category. (2) There is no significant difference in the increase of mathematical communication skills between students who get the cooperative learning model Question Students Have type and students who get Fishbowl type learning model. (3) Students' responses to mathematics learning using cooperative learning models Question Students Have type is in the "like" category while Fishbowl type is in the "really like" category.

Keywords: Mathematical Communication, Cooperative Learning, Students Have Questions, Fishbowl 


\section{PENDAHULUAN}

Matematika adalah salah satu ilmu pengetahuan yang sangat berguna untuk menyelesaikan masalah dalam kehidupan sehari-hari, baik dalam bidang perekonomian, ataupun dalam bidang lainnya. Matematika adalah salah satu mata pelajaran yang sangat penting, di mana sampai saat ini matematika selalu ada di jenjang pendidikan.

National Council of Teacher of Mathematics (Rachmayani, 2014) memaparkan bahwa pembelajaran matematika di jenjang pendidikan memerlukan standar pembelajaran yang bermanfaat untuk menghasilkan siswa yang mempunyai kemampuan berfikir, kemampuan komunikasi matematis, memiliki pengetahuan serta keterampilan yang bermanfaat. Hal ini sejalan dengan Pemendiknas 21 Tahun 2016, terdapat dua jenis standar pembelajaran: (1) Standar isi merupakan standar pembelajaran matematika yang berisi rancangan materi yang harus dipelajari oleh siswa (2) Standar proses mencakup: pemecahan masalah (problem solving), penalaran (reasoning), komunikasi (communication), penelusuran pola atau hubungan (connections), dan representasi (representatiation).

\section{A. Komunikasi Matematis}

Komunikasi (communication) merupakan salah satu standar proses pembelajaran. Komunikasi matematis adalah kemampuan siswa untuk menerangkan ide-ide matematika baik secara lisan maupun tertulis. Komunikasi melibatkan komunikator yang menyampaikan pesan kepada komunikan yang langsung memberikan tanggapan secara aktif.

Digambarkan sebagai berikut.
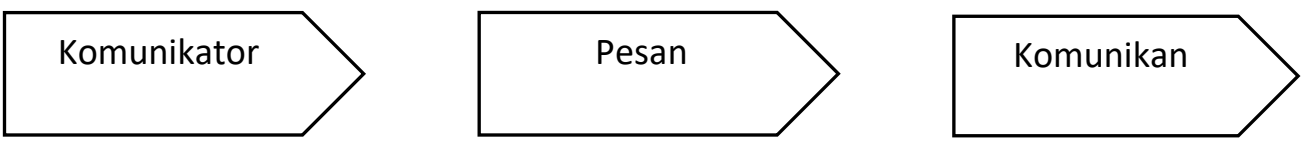

Penjelasan yang diberikan oleh Komariyatiningsih \& Kesumawati, (2012) bahwa komunikasi menjadi faktor penentu hubungan kita dengan makhluk lainnya, khususnya hubungan kita dengan sesama manusia. Oleh karena itu dibutuhkan keahlian dalam berkomunikasi untuk mencapai komunikasi yang efektif. Hal yang senada juga disampaikan oleh Sullivan \& Mousley (Nuraeni \& Luritawaty, 2016) bahwa komunikasi matematika bukan hanya sekedar menyatakan ide melalui tulisan tetapi lebih luas lagi yaitu kemampuan siswa dalam hal bercakap, menjelaskan, menggambarkan, mendengar, menanyakan, klarifikasi, bekerja sama (sharing), menulis, dan akhirnya melaporkan apa yang telah dipelajari. 
Adapun Sumarmo (Asnawati, 2012) menyatakan bahwa kemampuan komunikasi matematis meliputi kemampuan: (1) Menyatakan situasi, gambar, diagram, atau benda nyata ke dalam bahasa, simbol, ide, atau model matematika. (2) Menjelaskan ide, situasi, dan relasi matematika secara lisan atau tulisan. (3) Mendengarkan, berdiskusi, dan menulis tentang matematika. (4) Membaca dengan pemahaman suatu representasi matematika tertulis. (5) Mengungkapkan kembali suatu uraian atau paragraf matematika dalam bahasa sendiri.

\section{B. Pembelajaran Kooperatif}

Menurut Wendari \& Wendra (2014) model pembelajaran kooperatif merupakan konsep belajar berkelompok, yaitu siswa bekerja sama dalam suatu kelompok sebagai sebuah tim. Melalui penerapan model pembelajaran kooperatif, siswa akan menjadi lebih percaya diri karena siswa mendapat dukungan serta motivasi dari teman-teman satu tim. Dalam pembelajaran kooperatif, guru menciptakan suasana yang mendorong agar siswa merasa saling membutuhkan. Saling ketergantungan memungkinkan sesama siswa saling memberikan motivasi untuk meraih hasil belajar yang optimal. Hal ini senada dengan pernyataan Arif Rohman (2009) bahwa pembelajaran kooperatif (Cooperative learning) adalah model pembelajaran yang menekankan pada saling ketergantungan positif antar individu siswa, adanya tanggung jawab perseorangan, tatap muka, komunikasi intensif antar siswa, dan evaluasi proses kelompok.

Adapun tujuan dari model pembelajaran kooperatif menurut Nurfattahiyya (2013) adalah untuk membangkitkan perubahan konsep yang menawarkan suatu bentuk pengajaran yang memberikan kesempatan pada siswa berdiskusi dengan teman sebayanya dan gurunya. Siswa mengemukakan ide mereka secara langsung kepada teman sekelasnya dan gurunya kemudian membandingkan ide mereka dengan ide temanya untuk memperoleh sudut pandang yang berbeda, sehingga akhirnya dapat menilai kembali pendapat mereka.

\section{Pembelajaran Tipe Question Students Have}

Yusri Radhya (2015) menyatakan bahwa model yang diperkirakan dapat meningkatkan aktivitas belajar siswa dalam kelas adalah Questions Students Have. Dengan strategi ini diharapkan siswa mampu memahami konsep matematika, dimana siswa dituntut untuk lebih aktif dan mampu belajar dalam kelompok untuk memahami materi tersebut. Selama proses pembelajaran berlangsung hampir semua kegiatan pembelajaran dilakukan oleh siswa, guru hanya berperan sebagai fasilitator yang mengusahakan sumber belajar, sehingga dapat 
membantu pencapaian tujuan belajar. Karena model Questions Students Have ini mengharuskan setiap kelompok membuat pertanyaan dan menjawab sendiri pertanyaan tersebut setelah pertanyaan itu dibaca oleh kelompok yang lain. Langkah- langkah model pembelajaran Question Students Have menurut Nurfattahiyya (2013) sebagai berikut:

1. Bagikan potongan-potongan kertas (ukuran kartu pos) kepada siswa, yang di awali dengan penjelasan materi secara umum.

2. Minta setiap siswa untuk menuliskan satu pertanyaan apa saja yang berkaitan dengan materi pelajaran.

3. Setelah semua selesai membuat pertanyaan masing-masing di minta untuk memberikan kertas yang berisi pertanyaan kepada teman di samping kirinya. Dalam hal ini jika posisi duduk peserta didik adalah lingkaran nantinya akan terjadi gerakan perputaran kertas secara bergilir.

4. Pada saat menerima kertas dari teman di sampingnya, siswa di minta untuk membaca pertanyaan yang ada. Jika pertanyaan itu juga ingin dia ketahui jawabannya, maka dia harus memberi tanda centang, jika tidak ingin di ketahui atau tidak menarik berikan langsung pada teman di samping kiri

5. Ketika kertas pertanyaan tadi kembali kepada pemiliknya, Peserta didik diminta untuk menghitung tanda centang yang ada pada kertasnya. Pada saat ini carilah pertanyaan yang mendapat centang paling banyak.

6. Beri respon kepada pertanyaan-pertanyaan tersebut dengan: a) Jawaban langsung secara singkat, b) menunda jawaban sampai pada waktu yang tepat atau waktu membahas topik tersebut. Jawaban secara pribadi dapat diberikan di luar kelas.

7. Jika waktu cukup, minta beberapa orang peserta didik untuk membacakan pertanyaan yang ia tulis meskipun tidak mendapat tanda centang yang banyak kemudian beri jawaban.

8. Kumpulkan semua kertas, besar kemungkinan ada pertanyaan yang akan dijawab pada pertemuan berikutnya.

Catatan: Jika kelas terlalu besar sehingga akan memakan waktu yang banyak untuk dapat memutar kertas, pecahlah peserta didik menjadi kelompok yang lebih kecil kemudian ikuti intruksi seperti di atas. Atau dapat juga dengan mengumpulkan pertanyaan-pertanyaan tersebut tanpa diputar kemudian beberapa pertanyaan secara acak.

Berikut adalah kelebihan dan kelemahan dari model pembelajaran Question Students Have (QSH) menurut Rahmawati, (2015). Kelebihan Strategi QSH adalah (1) mengaktifkan siswa; (2) melatih rasa percaya diri siswa; (3) melatih siswa untuk berbuat jujur; (4) dapat 
meningkatkan penguasaan materi pelajaran; dan (5) dapat digunakan untuk semua mata pelajaran. Kekurangan Strategi QSH adalah (1) memakan banyak waktu jika digunakan dengan jumlah siswa banyak; (2) pertanyaan dari siswa sering kali tidak sesuai dengan topik yang dibahas.

\section{Pembelajaran Tipe Fishbowl}

Metode Fishbowl merupakan metode pembelajaran berdiskusi yang melibatkan keterampilan menyimak dan berbicara serta menuntut partisipasi aktif dari peserta diskusi. Menurut Silberman (Utami, 2014) metode Fishbowl memiliki bentuk kegiatan berdiskusi yang unik karena terdiri dari kelompok besar dan kelompok kecil yang membentuk dua lingkaran yaitu lingkaran besar dan lingkaran kecil dalam satu waktu dan tempat secara bersamaan. Kelompok kecil menempati posisi lingkaran kecil yang berada di dalam lingkaran besar. Peserta yang berada di lingkaran kecil inilah yang berperan sebagai ikan sedangkan peserta yang berada di lingkaran besar berperan sebagai pengamat di luar akuarium. Peran guru dalam metode Fishbowl hanya sebagai pembimbing dan pemberi topik diskusi saja. Saat kegiatan diskusi dimulai, guru berada di luar lingkaran diskusi untuk memantau serta mengontrol kegiatan berdiskusi. Jadi, hampir seluruh kegiatan diskusi dilakukan oleh siswa.

Adapun langkah-langkah pembelajaran kooperatif tipe Fishbowl menurut Silberman (Utami, 2014) adalah sebagai berikut:

1. Guru membuat beberapa pertanyaan yang berhubungan dengan materi yang akan dibahas.

2. Guru membagi kelas menjadi beberapa kelompok dan menentukan anggota kelompok pengamat dan anggota kelompok diskusi dalam setiap kelompok secara heterogen.

3. Mengatur tempat duduk tiap kelompok dalam kelas berbentuk 2 setengah lingkaran yaitu lingkaran luar dan lingkaran dalam kelompok pengamat berada dalam lingkaran luar dan kelompok diskusi berada di lingkaran dalam.

4. Anggota kelompok 1 menempati kursi lingkaran diskusi, dan anggota kelompok 2 dan 3 duduk di kursi lingkaran luar. Berikan pertanyaan pertama untuk didiskusikan dalam waktu 10 menit.

5. Siswa dalam sub kelompok pengamat mendengar, mengamati serta mencatat hal-hal yang berkaitan dengan materi yang sedang didiskusikan oleh sub kelompok diskusi.

6. Selanjutnya, mintalah kelompok 2 untuk duduk dilingkaran dalam, menggantikan para anggota kelompok 1 yang sekarang duduk di lingkaran luar. Tanyakan pada kelompok 2 apakah mereka mau meberikan komentar singkat tentang diskusi yang pertama, dan kemudian dilanjutkan dengan topik diskusi kedua. 
7. Ikuti langkah yang sama untuk kelompok selanjutnya

8. Setelah semua pertanyaan selesai diskusikan, kumpulkan kembali semua siswa menjadi satu lingkaran untuk membahas secara keseluruhan hasil dari pertanyaan yang telah didiskusikan tersebut.

Peserta-peserta dalam kelompok pengamat yang duduk melingkari kelompok diskusi berperan sebagai pengamat serta melakukan kegiatan mencatat. Setelah selesai seluruh peserta menganalisa dan mendiskusikan lebih dalam tentang permasalahan pada lembar kerja siswa yang diberikan. Tiap peserta diberikan kesempatan untuk mengemukakan analisanya. Sementara kelompok yang berada di dalam lingkaran berdiskusi, kelompok pendengar yang ingin menyumbangkan pikiran dapat masuk duduk menempati kursi kosong. Apabila ketua diskusi mempersilakan berbicara, ia dapat langsung berbicara, dan meninggalkan kursi setelah selesai berbicara.

Adapun kelebihan dan kekurangan menurut Silberman (Rahmiati \& Ningsih, 2014) adalah sebagai berikut: (1) Melatih siswa untuk belajar mengutarakan pendapat (2) Siswa dapat memperoleh penjelasan-penjelasan dari berbagai sumber (3) Memberikan kesempatan kepada siswa untuk dapat memecahkan masalah bersama (4) Mengembangkan rasa kepedulian serta menghargai pendapat dari orang lain (5) Menambah wawasan siswa terhadap masalah yang dibahas. Sedangkam Kekurangan Model Pembelajaran Fishbowl adalah (1) Alokasi waktu yang sulit karena banyak memakan waktu (2) Tidak semua siswa yang mengungkapkan pendapat (3) Jumlah kelompok yang kurang memadai.

\section{METODE PENELITIAN}

Penelitian ini dilakukan pada bulan Maret Semester Genap Tahun Ajaran 2017/2018. Tempat pelaksanaan penelitian ini di sekolah SD KARTIKA X-3 Parongpong, Waktu penelitian dilaksanakan pada 12 Februari 2018 sampai dengan 12 Maret 2018. Variabel dalam penelitian ini ada dua yaitu variabel bebas dan variabel terikat. Variabel bebas adalah model pembelajaran kooperatif tipe Question Students Have dan tipe Fishbowl. Sedangkan variabel terikat adalah kemampuan komunikasi matematis.

Pada penelitian ini peneliti memilih dua kelas siswa SD KARTIKA X-3 yaitu kelas VC adalah kelas 1 dan kelas VA adalah kelas 2. Dimana Kelas 1 dengan menerapkan model pembelajaran kooperatif tipe Question Students Have, dan untuk kelas 2 dengan menerapkan model pembelajaran kooperatif tipe Fishbowl.

Desain penelitian menurut Fraenkel dan Wallen (Cahyani, 2016) berikut: 


$\begin{array}{ccc}\text { Kelas } & \text { Variabel Bebas } & \text { Variabel Terikat } \\ 1 & \mathrm{X}_{1} & 0 \\ 2 & \mathrm{X}_{2} & 0\end{array}$

Keterangan:
A : Kelas 1
B : Kelas 2
$\mathrm{X}_{1}$ : Perlakuan menggunakan Pembelajaran Kooperatif tipe Question Students Have
$\mathrm{X}_{2}$ : Perlakuan menggunakan Pembelajaran Kooperatif tipe Fishbowl
0 : Tes Kemampuan Komunikasi Matematis Siswa

\section{HASIL PENELITIAN}

Pada bagian ini membahas hasil penelitian yang diambil dari siswa yang mengikuti pretes (mengetahui kemampuan awal siswa) dan postes (mengetahui kemampuan akhir siswa) pada kemampuan komunikasi matematis siswa. Terdapat 28 siswa kelas yang memperoleh pembelajaran tipe Question Students Have, dan 27 siswa yang memperoleh pembelajaran tipe Fishbowl. Data diolah dengan menggunakan bantuan software SPSS versi 24.0 for windows.

\section{Analisis Data Pretes}

Pembahasan tentang hasil pretes kemampuan komunikasi matematis siswa yang memperoleh pembelajaran tipe Question Students Have dan pembelajaran tipe

Fishbowl. dengan hasil yang diperoleh sebagai berikut ini:

Tabel 1 Hasil Deskriptif Data Pretes

\begin{tabular}{|c|c|c|c|c|c|c|c|}
\hline Kelas & $\mathrm{N}$ & Mean & SD & Minimum & Maksimum & Skewness & Curtosis \\
\hline $\begin{array}{c}\text { Question } \\
\text { Students Have }\end{array}$ & 28 & 16,428 & 3,248 & 9,000 & 22,000 & $-0,499$ & $-0,027$ \\
\hline Fishbowl & 27 & 15,148 & 4,166 & 7,000 & 22,000 & 0,104 & $-0,886$ \\
\hline
\end{tabular}

$\mathrm{SMI}=27$

Dari Tabel di atas, ditunjukkan bahwa hasil rata-rata pretes kemampuan komunikasi matematis yang dilakukan pada kelas yang memperoleh pembelajaran tipe Question Students Have lebih tinggi dibandingkan dengan pembelajaran tipe Fishbowl. Hal ini berarti bahwa, rata-rata skor pretes kemampuan komunikasi matematis siswa pada kedua kelompok adalah sedang. Pernyataan tersebut dapat di lihat dari skor maksimal ideal (SMI=27). Sedangkan standar deviasi siswa yang memperoleh pembelajaran tipe Fishbowl lebih kecil dari siswa yang memperoleh pembelajaran tipe Question Students Have. Artinya, sebaran data skor pretes kelas 
Question Students Have mendekati nilai rata-rata dibandingkan dengan sebaran data pada kelas Fishbowl.

Nilai Skewness yang didapatkan dari kelas yang memperoleh pembelajaran tipe Question Students Have adalah tanda negatif, artinya bahwa kurva condong ke kanan (nilai pretes kemampuan komunikasi matematis siswa lebih banyak menyebar di atas rata-rata). Dan sebaliknya pada kelas yang mendapatkan Fishbowl, nilai Skewness yang didapatkan pada kelas yang memperoleh pembelajaran tipe Fishbowl ini adalah tanda positif, artinya bahwa kurva condong ke kiri (nilai pretes kemampuan komunikasi matematis siswa lebih banyak menyebar di bawah rata-rata)

\section{A. Uji Normalitas Data Pretes}

Uji normalitas yang digunakan dalam penelitian ini adalah uji Shapiro-Wilk pada program SPSS 24,0 for windows. Hasil uji normalitas kemampuan komunikasi matematis siswa yang memperoleh pembelajaran tipe Qustion Students Have dan pembelajaran tipe Fishbowl pada Tabel 2 berikut:

Tabel 2 Hasil Uji Normalitas Data Pretes Kemampuan Komunikasi Matematis

\begin{tabular}{|c|c|c|c|c|}
\hline \multirow{2}{*}{ Kelas } & \multicolumn{3}{|c|}{ Shapiro-Wilk } & Keterangan \\
\cline { 2 - 4 } & Statistik & $\mathrm{df}$ & Sig. & \\
\hline $\begin{array}{c}\text { Question Students } \\
\text { Have }\end{array}$ & 0,962 & 28 & 0,419 & $\mathrm{H}_{0}$ tidak ditolak \\
\hline Fishbowl & 0,957 & 27 & 0,322 & $\mathrm{H}_{0}$ tidak ditolak \\
\hline
\end{tabular}

Berdasarkan hasil uji normalitas pada Tabel 2 terlihat bahwa nilai signifikan pretes dari pembelajaran tipe Question Students Have dan tipe Fishbowl lebih besar dari 0,05. Hal ini berarti masing-masing data pretes kemampuan komunikasi matematis dari kedua kelas berdistribusi normal.

\section{B. Uji Homogenitas Data Pretes Kemampuan Komunikasi Matematis}

Setelah diketahui bahwa data berdistribusi normal, maka akan diuji homogenitas pretes kemampuan komunikasi matematis siswa yang memperoleh pembelajaran tipe Quetion Students Have dan pembelajaran tipe Fishbowl. Hasil uji Homogenitas dapat dilihat pada Tabel 3 berikut.

Tabel 3 Hasil Uji Homogenitas Data Pretes

\begin{tabular}{|c|c|c|c|}
\hline & \multicolumn{2}{|c|}{ Levenes's Tes for Equality of Variances } & \multirow{2}{*}{ Keterangan } \\
\hline $\begin{array}{c}\text { Equal Variances } \\
\text { Assumed }\end{array}$ & $\mathrm{F}$ & Sig. & \\
\cline { 2 - 3 } & 2,418 & 0,126 & $\mathrm{H}_{0}$ tidak ditolak \\
\hline
\end{tabular}


Berdasarkan Tabel 3, hasil uji homogenitas kemampuan komunikasi matematis awal siswa menunjukkan bahwa nilai sig. adalah lebih besar dari 0,05 . Hal ini berarti bahwa data masing-masing kedua kelas berasal dari populasi yang memiliki varians homogen.

\section{Uji Beda Dua Rata-rata Data Pretes}

Karena data berdistribusi normal dan homogen, maka dapat dilanjutkan dengan uji beda dua rata-rata pretes kemampuan komunikasi matematis siswa menggunakan uji T-test pada taraf sig. 0,05. Hasil uji beda dua rata-rata yang ditunjukkan pada Tabel 4 berikut:

Tabel 4 Hasil Uji Beda Dua Rata-Rata Data Pretes

\begin{tabular}{|c|c|c|c|c|c|}
\hline \multirow{2}{*}{ Pre-tes KKM } & \multicolumn{2}{|c|}{ T-test for Equality of Means } & \multicolumn{2}{c|}{$\begin{array}{c}\text { T-test for Equality of } \\
\text { Means 95\% Cofidence } \\
\text { Interval of the Difference }\end{array}$} \\
\cline { 2 - 6 } & Sig. (2tailed) & $\begin{array}{c}\text { Mean } \\
\text { Difference }\end{array}$ & $\begin{array}{c}\text { Std. Error } \\
\text { Difference }\end{array}$ & Lower & Upper \\
\hline $\begin{array}{c}\text { Equal Variances } \\
\text { Assumed }\end{array}$ & 0,208 & 1,280 & 1,005 & $-0,735$ & 3,296 \\
\hline
\end{tabular}

Berdasarkan Tabel 4, hasil sig. (2-tailed) lebih besar dari 0,05, maka $\mathrm{H}_{0}$ tidak ditolak. Hal ini berarti tidak terdapat perbedaan yang signifikan pada kemampuan komunikasi matematis siswa yang memperoleh pembelajaran tipe Qustion Students Have dan pembelajaran tipe Fishbowl kemampuan. Artinya kemampuan awal kedua kelas sebelum mendapat perlakuan adalah sama.

\section{Analisis Data Postes}

Setelah kedua kelas mendapat perlakuan, maka penulis akan membahas hasil penelitian yang telah dilakukan, yaitu pembahasan tentang hasil postes kemampuan komunikasi matematis siswa yang memperoleh pembelajaran tipe Question Students Have dan pembelajaran tipe Fishbowl. Data diolah dengan menggunakan bantuan software SPSS versi 24.0 for windows dengan hasil yang diperoleh sebagai berikut ini:

Tabel 5 Hasil Deskriptif Data Postes

\begin{tabular}{|c|c|c|c|c|c|c|c|}
\hline Kelas & $\mathrm{N}$ & Mean & SD & Minimum & Maksimum & Skewness & Curtosis \\
\hline $\begin{array}{c}\text { Question } \\
\text { Students Have }\end{array}$ & 28 & 25,964 & 1,621 & 21,000 & 27,000 & $-1,904$ & 3,101 \\
\hline Fishbowl & 27 & 25,703 & 1,588 & 22,000 & 27,000 & $-1,025$ & $-0,277$ \\
\hline
\end{tabular}

$\mathrm{SMI}=27$

Tabel 5 di atas menunjukkan bahwa hasil postes kelas yang memperoleh pembelajaran tipe Question Students Have dan tipe Fishbowl mengalamai peningkatan, dengan nilai rata-rata 
postes yang lebih tinggi dari rata-rata pretes. Pernyataan ini dapat di lihat dari skor maksimal ideal $(\mathrm{SMI}=27)$. Dilihat dari standar deviasi, siswa yang memperoleh pembelajaran tipe Question Students Have lebih besar dari standar deviasi siswa yang memperoleh pembelajaran tipe Fishbowl. Hal ini berarti, sebaran data postes kelas Question Students Have menjauhi ratarata dibandingkan dengan sebaran data postes pada kelas Fishbowl.

Nilai Skewness yang didapatkan pada kedua kelas menunjukkan tanda negatif -1,904 dan -1,025, hal ini berarti bahwa data condong ke kanan (nilai postes kemampuan komunikasi matematis siswa lebih banyak menyebar di atas nilai rata-rata).

\section{Analisis Data Gain Ternormalisasi}

Pada bagian ini akan diuraikan hasil analisis data gain ternormalisasi terhadap kemampuan komunikasi matematis siswa yang memperoleh pembelajaran tipe Question Students Have dan pembelajaran tipe Fishbowl. Data diolah dengan menggunakan bantuan software SPSS versi 24.0 for windows dengan hasil yang diperoleh sebagai berikut ini:

Tabel 6 Hasil Deskriptif Data Gain Ternormalisasi

\begin{tabular}{|c|c|c|c|c|c|c|c|}
\hline Kelas & $\mathrm{N}$ & Mean & $\mathrm{SD}$ & Minimum & Maksimum & Skewness & Curtosis \\
\hline $\begin{array}{c}\text { Question } \\
\text { Students Have }\end{array}$ & 28 & 0,918 & 0,113 & 0,600 & 1,000 & $-1,460$ & 1,513 \\
\hline Fishbowl & 27 & 0,914 & 0,114 & 0,625 & 1,000 & $-1,015$ & $-0,010$ \\
\hline
\end{tabular}

Berdasarkan Tabel 6, memperlihatkan hasil dari gain ternormalisasi dari kelas yang memperoleh pembelajaran tipe Qustion Students Have dan tipe Fishbowl, dengan nilai ratarata kedua kelas ini adalah lebih besar dari 0,05, termasuk kategori tinggi jika dilihat dari indeks gain, $\mathrm{G} \geq 0,70$ dan standar deviasi juga adalah lebih besar dari 0,05 , artinya sebaran data skor gain mendekati nilai rata-rata. Nilai Skewness yang didapatkan dari kedua kelas menunjukkan tanda negatif -1,904 dan -1,025, artinya bahwa data condong ke kiri (kemampuan komunikasi matematis siswa lebih banyak meyebar di bawah rata-rata).

\section{A. Uji Normalitas Data Gain Ternormalisasi}

Uji normalitas yang dilakukan adalah uji normalitas pada gain ternormalisasi dari populasi kedua kelompok, yaitu nilai gain ternormalisai pada kelompok yang memperoleh pembelajaran tipe Qustion Students Have dan pembelajaran tipe Fishbowl melalui Tabel 7 berikut: 
Tabel 7 Hasil Uji Normalitas Data Gain Ternormalisasi

\begin{tabular}{|c|c|c|c|}
\hline \multirow{2}{*}{ Kelas } & \multicolumn{3}{|c|}{ Shapiro-Wilk } \\
\cline { 2 - 4 } & Statistik & df & Sig. \\
\hline Tipe Question Students Have & 0,316 & 27 & 0,000 \\
\hline Tipe Fishbowl & 0,243 & 27 & 0,000 \\
\hline
\end{tabular}

Berdasarkan hasil pada Tabel 7 tersebut, terlihat bahwa nilai signifikan gain ternormalisasi pada kelas pembelajaran tipe Question Students Have dan tipe Fishbowl lebih kecil dari 0,05. Hal ini berarti masing-masing populasi data dari kedua kelas tidak berdistribusi normal.

\section{B. Uji Homogenitas Data Gain Ternormalisasi}

Hasil uji homogenitas gain ternormalisasi kemampuan komunikasi matematis siswa ditunjukkan pada Tabel 8 berikut ini:

Tabel 8 Hasil Uji Homogenitas Data Gain Ternormalisasi

\begin{tabular}{|c|c|c|c|c|}
\hline \multirow{2}{*}{$\begin{array}{c}\text { Equal Variances } \\
\text { Assumed }\end{array}$} & $\mathrm{F}$ & $\mathrm{T}$ & \multicolumn{2}{c|}{$\begin{array}{c}\text { Tevenes's Tes for Equality of } \\
\text { Variances }\end{array}$} \\
\cline { 2 - 5 } & 0,101 & 0,751 & 0,455 & $\mathrm{~d}$ \\
\hline
\end{tabular}

Berdasarkan Tabel 8, hasil uji homogenitas kemampuan komunikasi matematis awal siswa menunjukkan sig adalah $0,751>0,05$. Hal ini berarti bahwa data gain ternormalisasi kelas berasal dari populasi yang memiliki varians homogen.

\section{Uji Beda Dua Rata-rata Data Gain Ternormalisasi}

Karena data gain ternormalisasi tidak berdistribusi normal, maka uji perbedaan dua median dilakukan dengan menggunakan uji Mann-Whitney pada taraf sig. 0,05. Hasil signifikansi uji beda dua rata-rata pada Tabel berikut:

Tabel 9 Hasil Uji Beda Dua Rata-Rata Data Gain Ternormalisasi

\begin{tabular}{|c|c|}
\hline Tes Statistik & Gain \\
\hline Mann-Whitney & 351,000 \\
\hline Wilcoxon W & 729.000 \\
\hline Z & $-0,484$ \\
\hline Asymp. Sig. (2-tailed) & 0,628 \\
\hline
\end{tabular}

Tabel 9 di atas, menunjukkan hasil sig. (2-tailed) adalah 0,628>0, 05, maka $\mathrm{H}_{0}$ tidak ditolak. Hal ini berarti tidak terdapat perbedaan pada peningkatan kemampuan komunikasi 
siswa yang memperoleh pembelajaran tipe Qustion Students Have dan pembelajaran tipe Fishbowl.

\section{Pembahasan Hasil Penelitian}

Setelah hasil penelitian di analisis, maka hasil yang diperoleh tidak sesuai dengan hipotesis awal dari penelitian ini. Dimana peningkatan kemampuan komunikasi matematis siswa yang memperoleh pembelajaran tipe Question Students Have dan tipe Fishbowl adalah sama, dengan kata lain tidak terdapat perbedaan antara kedua kelas. Berdasarkan hasil dari respon siswa, terlihat bahwa siswa sangat senang memperoleh model pembelajaran kooperatif tipe Question Students Have tergolong suka dan tipe Fishbowl tergolong sangat suka. Tetapi hasil dari uji beda dua rata-rata menunjukan bahwa tidak terdapat perbedaan yang signifikan antara siswa yang menggunakan model pembelajaran tipe Question Students Have dan tipe Fishbowl. Hal ini berarti siswa lebih antusias terdapat model pembelajaran Fishbowl karena tidak diharuskan untuk bertanya seperti pada model pembelajaran Question Students Have, yang menurut siswa kadang membebani pikiran mereka. Sementara, siswa yang menggunakan model pembelajaran Question Students Have dapat lebih memahami materi pelajaran karena harus menuliskan pertanyaan, tetapi tidak harus menyelesaikan soal secara individual.

\section{KESIMPULAN}

Berdasarkan hasil analisis data yang telah dikemukakan dalam bab sebelumnya, maka diperoleh beberapa simpulan sebagai berikut:

1. Kemampuan komunikasi matematis siswa sebelum memperoleh pembelajaran kooperatif tipe Question Students Have dan tipe Fishbowl tidak berbeda. Setelah mendapat perlakuan kemampuan komunikasi matematis siswa meningkat. Peningkatan kemampuan komunikasi matematis siswa yang memperoleh model pembelajaran kooperatif tipe Question Students Have dan siswa yang memperoleh model pembelajaran tipe Fishbowl yaitu berada pada kategori tinggi.

2. Tidak terdapat perbedaan yang signifikan pada peningkatan kemampuan komunikasi matematis antara siswa yang memperoleh model pembelajaran kooperatif tipe Question Students Have dan tipe Fishbowl.

3. Respon siswa terhadap pembelajaran matematika dengan mengunakan model pembelajaran kooperatif tipe Question Students Have berada pada kategori "suka" dan tipe Fishbowl berada pada kategori "sangat suka". 


\section{SARAN}

Berdasarkan hasil penelitiaan dan kesimpulan di atas, maka penulis merekomendasikan beberapa saran yang berhubungan dengan penelitian yang dilakukan berikut:

1. Kepada siswa agar melalui model pembelajaran kooperatif tipe Question Students Have dan tipe Fishbowl yang diterapkan dapat meningkatkan kemampuan siswa dalam mempelajari matematika serta memotifasi siswa dalam belajar.

2. Guru dapat mempertimbangkan model pembelajaran kooperatif tipe Question Students Have dan tipe Fishbowl sebagai salah satu mengajar di sekolah, agar tercipta cara belajar yang berbeda dari cara belajar sebelumnya dan diharapkan dapat meningkatkan kemampuan matematis yang lain.

3. Hasil penelitian kiranya dapat menjadi petunjuk bagi peneliti yang lain untuk dapat dilakukan penelitian yang lebih lanjut dengan variabel penelitian yang berbeda.

\section{DAFTAR PUSTAKA}

Asnawati. S (2012). Peningkatan Kemampuan Komunikasi Matematis Siswa Smp Dengan Pembelajaran Kooperatif Tipe Teams-Games-Tournaments. Program Studi Pendidikan Matematika FKIP Unswagati Cirebon Jurnal Euclid, ISSN 2355-1712, vol.3, No.2, pp. 474-603.

Cahyani. Y. (2016). Penggunaan Pembelajaran Kooperatif Tipe Fishbowl Dan Tipe Time Token Arends (TTA) untuk Meningkatkan Kemampuan Kumunikasi Matematis Siswa. No. FKIP: 062/MAT/VI/2016. Bandung, Jawa Barat. Universitas Advent Indonesia. (Skripsi).

Komariyatiningsih \& Kesumawati. (2012). Keterkaitan Komunikasi Matematis dengan Pendekatan Pendidikan Matematika. Program Studi Pendidikan Matematika FKIP Universitas PGRI Palembang. Prosiding, P - 68, ISBN: 978-979-16353-8-7.

Nuraeni \& Luritawaty. (2016). Mengembangkan Kemampuan Komunikasi Matematik Siswa melalui Strategi Think Talk Write. Jurnal "Mosharafa", Volume 8, Nomor 2. Jurnal Pendidikan Matematika STKIP Garut - jurnalmtk.stkip-garut.ac.id.

Nurfattahiyya. (2013). Penerapan Metode Pembelajaran Question Student Have untuk Mencapai Hasil Belajar Fisika Peserta Didik Kelas VII SMP Negeri 8 Makassar. Jurusan Pendidikan Físika, Fakultas Keguruan Ilmu Pendidikan, Universitas Muhammadiyah Makassar. JPF | Volume 2 | Nomor 2 | ISSN: 2302-8939 | 111.

Permendiknas. No. 21 (2016). http://bsnp-indonesia.org/wpcontent/uploads/2009/06/ Permendikbud_Tahun2016_Nomor 021_Lampiran.pdf

Priansa. (2017). Pengembangan Strategi dan Model Pembelajaran (Inovatif, Kreatif dan Prestatif dalam Memahami Peserta Didik). Penerbit PUSAKA SETIA Bandung. Cet. 1 April, 16 x 24 cm.; 372 hlm. ISBN: 978-979-076-657-0.

Rachmayani. (2014). Penerapan Pembelajaran Reciprocal Teaching Untuk Meningkatkan Kemampuan Komunikasi Matematis dan Kemandirian Belajar Matematika Siswa. Pendidikan Matematika Fip-Universitas Muhamadiyah Jakarta. Volume 2 Nomor 1. 
Rahmawati. L (2015). Pengaruh Penggunaan Strategi Question Student Have (QSH), Media Interaktif Ekosistem, Dan Kombinasinya Terhadap Hasil Belajar Siswa. Jurusan Biologi Fakultas Matematika Dan Ilmu Pengetahuan Alam Universitas Negeri Semarang 2015

Rahmiati \& Ningsih. (2014). Perbedaan Hasil Belajar IPA Antara Model Pembelajaran Fishbowl Dengan Model Pembelajaran Konvensional Siswa Kelas IV SDN Sertajaya 01 Cikarang Timur. PGSD FKIP-UHAMKA.

Utami. (2014). Keefektifan Metode Fishbowl terhadap Pembelajaran Berdiskusi Pada Siswa Kelas Viii Smp Negeri 5 Sleman. Program Studi Pendidikan Bahasa Dan Sastra Indonesia Fakultas Bahasa Dan Seni Universitas Negeri Yogyakarta. Skiripsi

Wedari. N.K.S \& Wendra. I.W at al. (2014). Penerapan Pembelajaran Kooperatif Teknik Keliling Kelompok Dengan Media Foto Jurnalistik Sebagai Upaya Meningkatkan Kemampuan Mengemukakan Pendapat Secara Lisan Siswa Kelas X3 SMA Negeri 1 Sukawati. Jurusan Pendidikan Bahasa dan Sastra Indonesia Fakultas Bahasa dan Seni Universitas Pendidikan Ganesha Singaraja, Indonesia. Tersedia: http://ejournal.undiksha.ac.id/index.php/JJPBS/article/viewFile/2944/2440

Yusri. (2015). Penerapan Strategi Questions Students Have Dalam Pembelajaran Matematika Pada Siswa Kelas X8 Sman 9 Padang. Program Studi Pendidikan Matematika STKIP PGRI Sumatera Barat. VOL II NO. 1, NOV 2015. 